\title{
RELEVANSI DALAM IKLAN SHOPEE COD: SEBUAH KAJIAN PRAGMATIK
}

\author{
Hanum Ulfah Nur Baiti, Febriyanti \\ hanum.ulfahnurb@gmail.com,febriyanti1888@gmail.com \\ UIN Syarif Hidayatullah Jakarta
}

Diserahkan: 19 Maret 2021, Direvisi: 29 April 2021, Diterima: 22 Juni 2021

\begin{abstract}
Speech in advertisements is a form of communication between an advertisment agency and its market share. Advertising agencies seek to influence their market share through symbols and speech contained in advertisements. According to Sperber and Wilson, the communication contained in advertisements is an extensive communication involving contextual effects and extensive stimulus that are known by market share. This article aims to dissect the relevance theory in Shopee COD advertising. The theory used in this study is the theory of relevance proposed by Sperber and Wilson. Relevance theory seeks to investigate advertisement utterances that ad agencies intend to convey to their market share. The method used in this research is a qualitative descriptive method with a pragmatic approach. The object of research in this study is the speech in the Shopee COD advertisement, while the data source is the Shopee COD video advertisement that airs on television. The findings obtained in this article are that the Shopee COD advertising agency wants to convey a message to friends, he said, namely Shopee users,
\end{abstract}


especially villagers, to shop at Shopee. Advertising agencies take advantage of a number of contextual effects such as the interlocutor's desire to shop at Shopee, trust, and payment methods and take advantage of extensive stimulus, namely songs and movements, orange colors, and repetition of the word Shopee COD.

Keywords: Relevance Theory, Pragmatic, Advertising, Marketplace

\begin{abstract}
Abstrak
Tuturan dalam iklan merupakan salah satu bentuk komunikasi antara agensi iklan dengan pangsa pasarnya. Agensi iklan berupaya memengaruhi pangsa pasarnya melalui simbol maupun tuturan yang terkandung dalam iklan. Menurut Sperber dan Wilson komunkasi yang terkandung dalam iklan merupakan komunikasi ostensif yang melibatkan efek kontekstual dan stimulus ostensif yang diketahui pangsa pasar. Artikel ini bertujuan untuk membedah teori relevansi dalam iklan Shopee COD. Adapun teori yang digunakan dalam penelitian ini dalah teori relevansi yang digagas oleh Sperber dan Wilson. Teori relevansi berupaya menyelidiki tuturan dalam iklan yang hendak disampaikan oleh agensi iklan kepada pangsa pasarnya. Metode yang digunakan dalam penelitian ini adalah metode deskriptif kualitatif dengan pendekatan pragmatik. Objek dalam penelitian ini adalah tuturan dalam iklan Shopee COD, sedangkan sumber data yaitu vidio iklan Shopee COD yang tayang di televisi. Temuan yang diperoleh dalam artikel ini adalah agensi iklan Shopee COD ingin menyampaikan pesan kepada kawan tuturnya, yaitu pengguna Shopee khususnya penduduk desa untuk belanja di Shopee. Agensi iklan memanfaatkan beberapa efek kontekstual seperti keinginan kawan tutur untuk belanja di Shopee, kepercayaan, dan metode pembayaran serta memanfaatkan stimulus ostensif yaitu berupa lagu dan gerakan, warna oranye, dan pengulangan kata Shopee COD.
\end{abstract}

Kata Kunci: Teori Relevansi, Pragmatik, Iklan, Marketplace 


\section{PENDAHULUAN}

Perkembangan teknologi memudahkan berbagai aktivitas manusia, salah satunya dalam bidang ekonomi. Kemudahan berbisnis hadir melalui marketplace. Marketplace merupakan ruang bertemunya penjual dan pembeli secara virtual. Yustiani dan Yunanto (2017: 45) menjelaskan bahwa marketplace merupakan salah satu model bisnis yang berkembang karena pesatnya pertumbuhan teknologi infomasi. Marketplace dirancang untuk meminimalisir porses bisnis yang kompleks agar tercipta efisiensi dan efektifitas. Marketplace saat ini menjadi primadona dalam kegiatan jual beli. Selain karena menghemat waktu dan tenaga, marketplace menyediakan berbagai pilihan barang dari berbagai toko dengan beragam kisaran harga. Penjual dapat dengan mudah membuka toko tanpa harus memiliki ruko, begitu pun pembeli dengan mudah mendapatkan barang yang diinginkan tanpa harus pergi ke toko. Penjual dan pembeli hanya cukup melakukan pendaftaran di aplikasi kemudian dengan bebas dapat membeli maupun menjual barang.

Situasi pandemi mengharuskan kita mengurangi berkegiatan di luar rumah, termasuk berbelanja. Tak heran jika akhir-akhir ini marketplace menjadi pilihan terbaik dan menjadi gaya hidup untuk memenuhi kebutuhan tanpa harus berinteraksi dengan banyak orang. Terdapat beberapa marketplace yang beredar di Indonesia, seperti; Shopee, Lazada, Tokopedia, Buka Lapak, Bli-bli, dan lain sebagainya. Marketplace tersebut memiliki ciri khas masing-masing. Meskipun demikian, secara keseluruhan marketplace tersebut banyak memiliki kesamaan mulai dari metode pembayaran, model pemasaran, hingga promo yang berlaku.

Shopee menjadi salah satu marketplace yang beredar di Indonesia. Mengusung slogan "No. 1 belanja online, belanja kapanpun dimanapun "menjadikan Shopee sebagai marketplace paling populer di kalangan milenial. Berdasarkan infomasi yang tertera di playstore, lebih dari 100 juta pengguna telah mengunduh aplikasi Shopee. Hal tersebut menunjukkan eksistensi Shopee. Walaupun demikian, Shopee terus meningkatkan pelayanan baik 
dari segi fitur, promo, hingga pemasaran. Peningkatan pelayan tersebut disampaikan melalui iklan yang beredar di berbagai media.

Iklan sangatlah penting dalam dunia bisnis. Adanya iklan diharapkan dapat meningkatkan jumlah penjualan maupun pemakai aplikasi. Selain sebagai alat informasi, iklan bagi pelaku usaha berfungsi untuk memasarkan produknya, menaikan jumlah penjualan, dan dianggap sebagai media yang ampuh untuk menarik konsumen agar membeli produk (Simatupang, 2004: 9). Purnama (2001:156) medefinisikan iklan sebagai bentuk presentasi nonpersonal dan promosi ide, barang, maupun jasa di media massa dan dibayar oleh sponsor tententu. Persaingan yang ketat mendorong perusahaan untuk membuat iklan yang menarik perhatian pangsa pasar untuk membeli atau memanfaatkan jasa yang ditawarkan oleh agensi iklan.

Secara berkala Shopee menampilkan pembaruan iklan yang disesuaikan dengan kebutuhan pasar. Iklan tersebut ditayangkan di berbagai media. Saat ini media penyampaian iklan lebih luas, jika dulu iklan hanya dapat ditampilkan di media cetak (koran, majalah, brosur), televisi, dan radio, maka saat ini media penyampaian iklan beragam. Media sosial mejadi salah satu target penyampaian iklan. Tayangan iklan sering kali muncul di media sosial, begitu pula iklan Shopee. Iklan Shopee yang terbaru dan menarik adalah iklan Shopee COD. Ciri khas iklan Shopee biasanya selalu mengolaborasikan musik, lagu, tari, dan tak jarang Shopee menggunakan idol-idol Korea untuk menarik perhatian kaula muda. Sama seperti iklaniklan sebelumnya, iklan Shopee COD juga menggabungkan musik dengan tarian, namun kali ini Shopee menggaet artis lokal yaitu Tukul Arwana.

Iklan yang tayang pada bulan Februari 2021 tentu merupakan salah satu bentuk peningkatan pelayanan perusahaan. Shopee COD menjadi tuturan unggulan dalam iklan tersebut. Tuturan yang terdapat dalam iklan Shopee COD tentu memiliki makna pragmatis. Agensi iklan ingin mengimbau pangsa pasar untuk tertarik berbelanja melalui aplikasi Shopee dengan segala kemudahannya. Tuturan yang 
disampaikan dengan unik diharapkan mampu memengaruhi pangsa pasar sehingga tujuan dari agensi iklan tercapai.

Tuturan yang terdapat dalam iklan dapat dikaji mengggunakan pendekatan pragmatik dengan teori relevansi. Pendekatan pragmatik melihat bahwa tuturan dalam iklan merupakan bagian dari komunikasi antara agensi iklan sebagai penutur dan pangsa pasar sebagai kawan tutur. Ketika seseorang membaca maupun menonton iklan, sesungguhnya telah terjadi komunikasi tidak langsung antara agensi iklan dengan pangsa pasarnya. Teori relevansi beranggapan bahwa dalam iklan kawan tutur berusaha menafsirkan tuturan iklan dengan pengetahuan dan asumsi dalam pangsa pasarnya (Nurjanah, 2016:69). Seperti halnya sebuah komunikasi langsung, sifat iklan yang persuasif sangat menarik untuk diteliti. Pragmatik dalam linguistik mengkaji tuturan dengan memperhatikan sebuah konteks, begitupun tuturan dalam ikan juga dapat dikaji konteks dan maknanya sehingga memengaruhi pangsa pasar.

Mengkaji iklan menggunakan teori relevansi artinya melakukan penyelidikan terhadap tuturan yang terkandung dalam iklan yang hendak disampaikan oleh agensi iklan. Tuturan yang disampaikan oleh agensi iklan nantinya akan ditafsirkan oleh pangsa pasar sebagai kawan tutur. Menurut Tanaka (dalam Nurjanah, 2016: 69) teori relevansi menyediakan catatan yang komprehensif mengenai penafsiran sebuah tuturan. Dengan demikian, teori relevansi menjadi alat analisis yang tepat dalam mengkaji sebuah iklan yang mengandung tuturan untuk disampaikan kepada pangsa pasar.

Masalah dalam penelitian ini dirumuskan dalam pertanyaan berikut "Bagaimana teori relevansi yang terkandung dalam iklan Shopee COD?” Berdasarkan pada rumusan masalah tersebut, maka dapat dikemukakan beberapa pertanyaan penelitian yaitu: (1) Siapakah kawan tutur dari iklan Shopee COD?(2) Bagaimanakah efek kontekstual dan stimulus ostensif dalam iklan Shopee COD?(3) Apakah maksud yang ingin diungkapkan agensi iklan?(4) Bagaimanakah derajat relevansi tuturan dalam iklan Shopeee COD? 
Penelitian ini bertujuan untuk memeroleh pemahaman tentang teori relevansi khusunya pada iklan Shopee COD.

\section{KAJIAN LITERATUR}

\section{Pragmatik}

Pragmatik adalah studi tentang bagaimana agar lebih banyak yang disampaikan daripada yang dituturkan (Putrayasa, 2014:2). Sperber dan Wilson (2005: 268) mengartikan pragmatik sebagai sebuah kajian tentang penggunaan bahasa yang sering dibedakan atau dikontraskan dengan kajian struktrur bahasa. Sejalan dengan itu, menurut Nadar (2013:2) pragmatik merupakan cabang linguistik yang memelajari bahasa yang digunakan untuk berkomunikasi dalam situasi tertentu. Pragmatik dapat diartikan sebagai disiplin ilmu yang membahas bahasa dengan makna yang tidak terpisahkan dengan konteks sehingga menghasilkan makna kawan tutur. Konteks merupakan hal terpenting dalam kajian pragmatik. Artinya, pragmatik merupakan bidang ilmu bahasa yang mengkaji fungsi dan maksud tuturan atau ujaran (Harmaji dalam Lutfiyani, dkk, 2020: 271). Secara sederhana Kushartanti (2009:104). menjelaskan bahwa pragmatik merupakan cabang ilmu linguistik yang mengkaji makna tuturan yang dipengaruhi oleh hal-hal di luar bahasa. Begitu pula dengan Yule (2006: 112) mengemukakan bahwa pragmatik adalah ilmu yang mengkaji tentang apa makna yang disampaikan penutur dan makna yang diterima oleh mitra tutur.

Objek kajian pragmatik berupa tuturan wacana, baik berupa percakapan maupun bentuk lainnya yang berisifat interaktif atau noninteraktif. Berdasarkan pengertian di atas, pada penelitian ini menggunakan pendekatan pragmatik yang mengkaji tuturan yang terdapat dalam iklan Shopee COD.

\section{Teori Relevansi}

Adapun teori relevansi yang digunakan dalam analisis ini adalah teori relevansi milik Daniel Sperber dan Deirde Wilson. Mereka menjelaskan bahwa teori relevansi adalah suatu teori kognisi 
yang memiliki dasar pemikiran bahwa komunikasi merupakan sebuah proses memperluas kesamaan lingkungan kognitif antara penutur dan kawan tutur (Sperber dan Wilson, 1995:158). Teori relevansi menjadi salah satu teori dalam kajian pragmatik yang mengharuskan adanya kesesuaian antara pertanyaan dan jawaban dalam sebuah komunikasi. Penutur dan kawan tutur harus menginterpretasikan sebuah tuturan dengan pemahaman yang sama (Megawati, 2018:18).

Berkomunikasi merupakan cara untuk menyampaikan pesan, penerimaan dan penyampain infomasi harus relevan, sehingga tujuan komunikasi dapat tercapai. Gagasan tersebut yang mendasari Spenser dan Wilson menggagas prinsip komunikasi relevan. Mereka beranggapan bahwa prinsip tersebut sangat penting dalam sebuah komunikasi karena dalam prinsip tersebut menunjukan bagaimana melihat interaksi linguistik dan konteks di dalam mengintepretasikan sebuah tuturan. Prinsip relevansi milik Sperber dan Wilson dirumuskan sebagai prinsip yang menjadi landasan komunikasi ostentif yang berisikan jaminan adanya relevansi optimal (Nasiu, 2007:9). Efek kontekstual sangat penting dalam teori relevansi sebab sebuah komunikasi dikatakan relevan apabila memiliki efek kontekstual.

Adapun teori relevansi milik Sperber dan Wilson mecoba mengritisi prinsip kerja sama miliki Grice. Berdasarkan prinsip kerja sama, antara penutur dan kawan tutur hendaknya mematuhi prinsip kerja sama dengan baik. Tujuan dari prinsip kerja sama Grice adalah untuk mendeskripsikan tentang penutur dan kawan tutur dalam percakapan. Menurut Grice dalam percakapan harus mematuhi empat maksim kerja sama yaitu maksim kuantitas, maksim kualitas, maksim relevansi, dan maksim cara (Grice, 1975: 47). Grice berpendapat bahwa komunikasi yang baik harus memenuhi empat maksim tersebut. Rahardi (dalam Normalita, 2020: 214) menjelaskan saat berkomunikasi peserta tutur perlu mempertimbangkan prinsip-prinsip berikut; 1) kejelasan, 2) kepadatan, dan 3) prinsip kelangsungan yang telah dituangkan di dalam prinsip kerja sama Grice. Meskipun demikian, nyatanya dalam sebuah komunikasi 
tidak semua maksim dalam prinsip kerja sama Grice dipatuhi. Misalnya dalam percakapan yang terjadi antara Lia dan Fais sebagai berikut:

Lia : (1) Is, mau ke sana? (Lia menyapa Fais yang berjalan mendahuluinya)

Fais : (2) Iya Li, gabung yuk! (Fais berhenti dan menoleh ke arah Lia)

Lia : (3) Oke, nanti gue nyusul.

Sekilas percakapan di atas tidak memiliki kesinambungan antartuturannya, namun ternyata tuturan dalam percakapan di atas relevan dan berkaitan satu dengan yang lainnya. Percakapan berjalan dengan baik dan relevan sebab antara penutur dan kawan tutur memiliki asumsi yang mengantarkan keduanya pada makna yang sama. Asumsi yang dilibatkan dalam percakapan di atas adalah (a) Fais hendak pergi ke suatu tempat, (b) Tempat tersebut merupakan tempat yang biasanya mereka gunakan untuk bermain. Fais yang memiliki mamahami maksud tuturan Lia dan memiliki asumsi yang sama, maka Fais menjawab pertanyaan Lia dengan melibatkan asumsi bahwa, (c) Ia ingin pergi ke suatu tempat, (d) tempat yang akan ia datangi merupakan tempat yang biasa ia gunakan saat bermain dengan Lia. Pada percakapan di atas, menurut Sperber dan Wilson yang paling penting dalam komunikasi adalah bagaimana sebuah ujaran dari penutur dapat dipahami berdasarkan lingkungan kognitif kawan tuturnya (Nurjanah, 2016:71). Dapat simpulkan jika empat maksim Grice dapat digugurkan apabila dapat percakapan penutur dan kawan tutur mematuhi maksim relevansi.

Tasanius (dalam Nurjanah dan Pratiwi, 2019:79) menjelaskan bahwa Sperber dan Wilson merumuskan prinsip relevansi berdasarkan komunikasi ostentif. Pada komunikasi ostentif terdapat jaminan komunikasi yang relevan. Dengan menggunakan bahasa yang sederhana, komunikasi ostentif terjadi ketika kawan tutur memahami maksud yang disampaikan oleh penutur. Apabila komunikasi tidak relevan, maka komunikasi tersebut tidak ostentif dan tidak memenuhi 
maksim relevansi. Pada teori relevansi juga terdapat derajat relevansi yang didapat dari efek kontekstual.

\section{Iklan}

Iklan sebagai suatu bentuk komunikasi nonpersonal yang menyampaikan infomasi berbayar sesuai keinginan dari instutisi/ sponsor melalui media massa yang bertujuan memengaruhi khalayak agar membeli suatu produk atau jasa (Jaiz, 2014:2). Sejalan dengan itu, Kotler (2007: 244) menjelaskan bahwa iklan merupakan sebuah bentuk penyajian dan promosi ide, barang maupun jasa secara nonpersonal oleh suatu sponsor tertentu yang memerlukan biaya. Terdapat indikator-indikator untuk mengukur periklanan adalah; 1) memberikan informasi (to inform), 2) membujuk (to persuade), dan 3) mengingatkan (to remind) (Kotler dalam Haryani, 2019:58). Sebuah iklan dikatakan efektif apabila pesan yang terkandung di dalamnya mampu tersampaikan dengan baik, untuk menyampaikan pesan tersebut tentu dibutuhkan sebuah strategi (Oktafiandi, 2018: 2). Berdasarkan penjelasan di atas maka dapat disimpulkan bahwa iklan merupakan sebuah bentuk komunikasi nonpersonal yang mengandung pesan dan berusaha memengaruhi khalayak agar menggunakan barang atau jasa yang ditawarkan sehinga perlu adanya strategi penyampaian pesan agar tujuan dari iklan tercapai.

\section{Marketplace}

Salah satu pemanfaatan teknologi dalam bidang ekonomi adalah kegiatan jual beli online menggunakan marketplace. Menurut Apriyadi (dalam Wulandari:2020) menjelaskan bahwa marketplace merupakan sebuah wadah untuk memasarkan produk secara elektronik dengan mempertemukan penjual dan pembeli untuk saling berinteraksi. Sejalan dengan Apriyadi, Artaya dan Purworusmiadi (2019) menjelaskan bahwa marketplace adalah sebuah pasar elektronik yang melakukan kegiatan menjual dan membeli suatu barang ataupun jasa yang meliputi 3 Aspek (b2b, b2c, c2c) di mana (Bisnis to Bisnis) mendominasi hinggga 75\%. Kodong, dkk (2012:76) menjelaskan bahwa marketplace hadir dengan memanfaatkan internet untuk menciptakan suatu lingkungan yang 
mewadahi para penjual dan pembeli untuk melakukan prosesproses bisnis mulai dari pemasaran produk, penawaran produk, mengembangkan komunikasi antara penjual dan pembeli sehingga tercapai kepuasan terhadap keduanya.

Imam dan Nugraha (2018: 162) menjelaskan bahawa transaksi di dalam marketplace dikelolola langsung oleh manajemen marketplace. Marketplace menyediakan pengelolaan pembayaran, katalog penjualan, stok produk serta informasi mengenai penjual dan pembeli. Harga yang ditetapkan pun sudah pasti sehingga tidak ada tawar menawar. Adapun keuntungan dari memanfaatkan marketplace di antaranya: memperluas jaringan pasar, meningkatkan penjualan, hemat biaya, tidak terbatas oleh waktu dan tempat, serta pilihan barang lebih banyak. Berdasarkan beberapa teori di atas, dapat disimpulkan bahwa marketplace merupakan sebuah pasar modern yang mempertemukan penjual dan pembeli secara virtual dengan sistem kerja yang sudah ditentukan oleh manajemen yang bersangkutan.

Penelitian yang berkaitan dengan teori relevansi masih sedikit dilakukan. Meskipun demikian, analisis menggunakan teori relevansi dengan pendekatan pragmatik pernah dilakukan. Sebuah penelitian yang berjudul Citra Perempuan Berhijab dalam Iklan Shampo: Sebuah Kajian Pragamatik yang ditulis oleh Neneng Nurjanah dan Rifka A. Partiwi dari UIN Syarif Hidayatullah Jakarta. Penelitian tersebut dimuat dalam jurnal Pena Indonesia, volume 5, nomor 2, pada Oktober 2019.

Penelitian lainya ditulis oleh Megawati dari Universitas Indonesia dengan judul Analisis Teori Relevansi dalam Acara Ini Talkshow sebagai Kritik Terhadap Prinsip Kerja sama Grice. Tulisan tersebut terbit tahun 2018 di jurnal Unis Tangerang. Dalam penelitian tersebut Megawati ingin melihat bagaimanana teori relevansi digunakan untuk melanggar maksim kerja sama Grice namun komunikasi tetap berjalan dengan baik. Sama dengan penelitian yang ditulis oleh Nurjanah, Megawati juga menggunakan metode deskriptif kualitatif dengan objek penelitian tuturan dalam acara Ini Talkshow. 
Sulfia Puspitasari pada tahun 2015 menulis sebuah skripsi dengan judul Study of Conceptual Metaphors in Indomie Tv Commercial. Penelitian tersebut menjelaskan terkait konsep dan makna metafora yang terkandung dalam iklan tv Indomie. Pada penelitiannya, Puspitasari menggunakan pendekatan kualitatif dengan menggunakan teori konsep miliki Lakoff dan Johnson. Sama dengan penelitian ini, Puspitasari juga menggunakan teori relevansi milik Sperber dan Wilson untuk mengetahui makna dibalik konsepkonsep yang terkandung dalam iklan Indomie.

\section{METODE PENELITIAN}

Metode yang digunakan dalam penelitian ini adalah metode deskriptif kualitatif. Metode deskriptif kualitatif merupakan metode penelitian yang menganalisis data dalam bentuk kata-kata dan bahasa. Hal tersebut sejalan dengan pendapat Sugiyono (dalam Putri, 2020: 26) bahwa penelitian kualitatif merupakan metode penelitian naturalistik karena penelitiannya dilakukan pada kondisi yang alamiah serta data yang terkumpul analisisnya lebih bersifat kualitatif. Fokus penelitian ini adalah untuk mendeskripsikan dan interpretasi data. Sumber data dalam penelitian ini terbagi mejadi data primer dan data sekunder. Data primer didapatkan berupa vidio iklan Shopee COD yang tayang di televisi. Iklan tersebut dapat juga dapat disaksikan di kanal Youtube AnggaFer' yang diunggah pada 15 Februari 2021 atau dapat diunduh pada tautan https://youtu. be/bGvkxCMX30c. Sementara itu, data sekunder merupakan data penunjang penelitian. Data sekunder didapat dari buku dan sumber bacaaan lainnya yang terkait dengan penelitian, antara lain; buku pragmatik, karya-karya ilmiah yang relevan dengan penelitian, dan lain sebagainya. Objek penelitian ini adalah tuturan yang terdapat dalam iklan tersebut. Tuturan tersebut berupa lirik lagu dan gambar maupun tulisan yang dimuat dalam iklan. Pengumpulan data dilakukan menggunakan teknik simak yaitu menyaksikan video iklan Shopee COD dan melakukan transkip data serta mencatat poin-poin analisis. Setelah data terkumpul peneliti melakukan analisis data dengan menggunakan teori relevansi. 


\section{HASIL PENELITIAN DAN PEMBAHASAN}

Berdasarkan pertanyaan penelitian, analisis iklan Shopee COD memiliki empat tahap. Analisis pertama mengenai kawan tutur iklan Shopee COD; kedua, analisis terkait efek kontekstual yang terdapat dalam tuturan iklan Shopee COD; ketiga, analisis maksud agensi iklan melalui tuturan dalam iklan Shopee COD; dan keempat yaitu analisis derajat relevansi iklan Shopee COD.

\section{Kawan Tutur Iklan Shopee COD}

Kawan tutur dalam sebuah iklan ialah pangsa pasar yang menjadi sasaran agensi iklan dalam menawarkan produk atau jasanya. Cook (dalam Nurjanah, 2016: 77) menyebutkan bahwa pangsa pasar dapat dipilah berdasarkan gender, stratifikasi sosial, usia, dan lain-lain. Kawan tutur dalam iklan biasanya ditampilkan dalam bentuk simbol-simbol yang merepresentasikan kawan tutur sehingga terjalin komunikasi yang baik antaragensi iklan (penutur) dengan pangsa pasar (kawan tutur).

Iklan Shopee COD menampilkan Tukul Arwana sebagai model utama yang berperan sebagai kurir. Selain itu juga terdapat model pendukung dengan berbagai latar belakang pekerjaan, pemilik warung makan sederhana, peternak, petani, tukang ojek, dan kuli bangunan. Pekerjaan-pekerjaan tersebut merepresentasikan kehidupan desa yang identik dengan perekonomian yang rendah. Hal tersebut diperjelas melalui tayangan yang ditampilkan dalam iklan. Latar pedesaan daerah pegunungan dan pesawahan ditampilkan dalam video tersebut. Agensi iklan ingin menampilkan kesederhanaan kehidupan di desa. Kesederhanaan tersebut ditampilkan melalui kegiatan masyarakatnya serta pekerjaan yang dimiliki, seperti petani yang sedang menanam padi di sawah, peternak yang sedang mengembala ternaknya, tukang ojek, kuli bangunan yang sedang membangun rumah, hingga pemilik warung sederhana dengan dinding anyaman bambu.

Pada iklan Shopee COD, pangsa pasar menggunakan bahasa yang sederhana, singkat, dan jelas. Adapun kalimat yang muncul dalam iklan yang berdurasi 30 detik tersebut adalah sebagai berikut: 
"Shopee COD, bayar langsung di tempat, tanpa tabungan, tanpa rekening, pasti dapat gratis ongkir, pasti dijamin aman." Pemilihan kalimat yang sederhana tersebut merepresentasikan kawan tutur dengan tingkat pendidikan yang rendah sehingga bahasa yang dipilih adalah bahasa yang sederhana agar mudah dipahami kawan tutur. Melalui gambar dan bahasa yang digunakan dalam iklan Shopee COD tersebut, agensi iklan ingin berkomunikasi dengan pangsa pasarnya atau kawan tuturnya yaitu masyarakat pedesaan dengan kategori usia dewasa, yaitu 17 tahun ke atas dan hidup dengan penuh kesederhaan, kurang mendapatkan pendidikan yang memadai, serta memiliki taraf perekonomian menengah ke bawah. Pangsa pasar dengan kriteria tersebut dianggap mengalami kesulitan ketika ingin berbelanja di Shopee, sehingga agensi iklan memberikan pelayanan baru berupa sistem pembayaran COD yang memudahkan pangsa pasar dalam berbelanja di Shopee khususnya penduduk desa. Meskipun demikian, tidak menutup kemungkinan bahwa layanan Shopee COD digunakan oleh masyarakat perkotaan dan milenial.

\section{Efek Kontekstual dan Stimulus Ostensif dalam Iklan Shopee COD}

Efek kontekstual dan stimulus ostensif sangat penting dalam sebuah komunikasi. Dalam teori relevansi, efek kontekstual yang memengaruhi relevan tidaknya sebuah komunikasi. Sementara itu, efek kontekstual dalam iklan berfungsi untuk menyusun strategi pemasaran. Efek kontekstual adalah anggapan yang dimiliki oleh agensi iklan sebagai penyedia jasa dan asumsi yang dimiliki oleh pangsa pasar. Dengan efek kontekstual tersebut, pangsa pasar mengetahui strategi apa serta tuturan apa yang dapat memengaruhi pangsa pasar. Stimulus ostensif hadir berupa simbol-simbol yang ditampilkan, dapat berupa tuturan maupun gambar guna menarik perhatian pangsa pasar. Ada beberapa anggapan yang terkandung dalam iklan Shopee COD yaitu anggapan bahwa masyarakat desa ingin berbelanja melalui Shopee, anggapan terkait kepercayaan, dan anggapan terkait metode pembayaran yang digunakan dalam belanja online. Anggapan-anggapan tersebut yang mendorong agensi iklan membuat sebuah iklan. 
Anggapan pertama, mengenai keinginan penduduk desa untuk berbelanja di Shopee. Penduduk desa memang lebih tertinggal jika dibandingkan dengan penduduk kota. Fasilitas yang kurang memadai menjadi salah satu penyebab ketertinggalan. Meskipun penduduk desa lebih tertinggal jika dibandingkan dengan penduduk kota, bukan berarti mereka tidak memiliki keinginan yang sama dengan penduduk di kota. Kecanggihan teknologi yang kerap kali menampilkan iklan suatu produk atau jasa kerap kali menimbulkan dorongan akan sifat konsumerisme. Artinya, penduduk desa yang berperan sebagai konsumen juga ingin membeli produk yang ditawarkan. Salah satu kendala penduduk desa dalam memenuhi kebutuhan maupun keinginannya adalah minimnya sinyal dan sulitnya akses untuk bepergian.

Anggapan mengenai keinginan penduduk desa untuk belanja di Shopee namun terkendala fasilitas dimanfaatkan oleh agensi iklan untuk menawarkan kemudahan, yaitu belanja di Shopee dengan sistem pembayaran COD (bayar langsung di tempat) sehingga pembeli dalam hal ini penduduk desa tidak harus kesulitan dalam melakukan transaksi pembayaran.

Anggapan kedua, mengenai kepercayaan. Berbelanja online kerap kali menimbulkan ketakutan bagi pembeli. Anggapan yang berkembang di masyarakat bahwa belanja online berisiko penipuan, barang tidak sampai, barang cacat, hingga barang palsu yang tentunya hal tersebut merugikan pembeli. Banyaknya kasus penipuan dalam dunia maya, termasuk pada kegiatan jual-beli online. Penipuan tersebut menjadi alasan mengapa belanja online di marketplace kurang dipercaya. Kondisi kehidupan penduduk desa yang perpenghasilan rendah serta kualitas pendidikan rendah hingga kurangnya infomasi merupakan suatu tantangan bagi agensi iklan khususnya perusahaan marketplace dalam menumbuhkan kepercayaan untuk berbelanja online.

Ketakutan terbesar pembeli jika belanja online adalah uangnya hilang cuma-cuma sedangkan barang tak didapat. Bagi penduduk desa, uang sangat berharga. Pekerjaan yang dianggap kurang 
prestisius dengan penghasilan rendah mengharuskan penduduk desa memanfaatkan uang dengan sebaik-baiknya. Jangan sampai uang terbuang sia-sia kerena terkena penipuan saat berbelanja online. Agensi iklan memanfaatkan asumsi tersebut dengan menawarkan belanja aman di Shopee yaitu dengan sistem pembayaran COD. Berbelanja di Shopee dengan sistem COD menjadi antitesa ketakutan dalam berbelanja online, sebab pembeli baru akan membayar jika barang yang dibeli telah sampai di tangan, sehingga pembeli tidak perlu khawatir akan penipuan dan merugi karena kehilangan uangnya dengan cuma-cuma.

Anggapan ketiga, mengenai metode pembayaran yang digunakan ketika berbelanja online. Banyak metode pembayaran yang dapat digunakan ketika belanja online di marketplace; seperti transfer bank, kartu kredit/debit; melalui minimarket, dan paylater. Beragam metode pembayaran tersebut memiliki kelebihan dan kekurangan Pembayaran melaui transfer bank dan kartu kredit tanpa dipungut biaya admin, namun saldo harus mencukupi. Selain itu, apabila pembeli tidak memiliki e-banking maka pembeli harus pergi ke ATM terdekat, hal tersebut tentu memerlukan waktu dan tenaga tambahan. Pembayaran melalui minimarket cukup dengan pergi ke minimarket terdekat dan menyebutkan kode pembayaran kepada kasir. Kerugian menggunakan metode pembayaran ini selain memerlukan tambahan waktu dan tenaga, pembeli juga dikenai biaya tambahan pelayanan. Paylater menawarkan sistem kredit, di mana barang dapat di bayar dengan cara cicil di kemudian hari, namun dikenai biaya tambahan.

Metode-metode tersebut sangat mudah dilakukan jika berada di kota, di mana masyarakatnya berpendidikan tinggi, akses infomasi, dan fasilitas mudah didapat, namun tidak dengan penduduk desa. Anggapan tersebut dimanfaatkan oleh agensi iklan Shopee COD untuk menawarkan metode pembayaran COD. Metode pembayaran tersebut dianggap lebih mudah dan efektif bagi pembeli khususnya penduduk desa, karena pembeli tidak harus bepergian dan tanpa dikenai biaya tambahan. 
Seperti penjelasan sebelumnya, bahwa efek kontekstual merupakan anggapan yang dimiliki oleh agensi iklan dan asumsi yang beredar di benak pangsa pasar. Pada teori relevansi, keberadaan efek kontekstual sangat penting agar komunikasi dapat berjalan dengan relevan. Efek kontekstual dimanfaatkan oleh agensi iklan untuk melakukan pembaruan informasi yang dimilki oleh kawan tutur. Berdasarkan tuturan yang terdapat dalam iklan tersebut, agensi iklan memberikan informasi mengenai kemudahan berbelanja di Shopee. Shopee hadir dengan metode pembayaran baru yaitu COD bayar langsung di tempat. Pembayaran COD dapat dilakukan oleh siapapun dan dimanapun, khusunya penduduk desa. Tuturan yang terdapat dalam iklan dimaksudkan agar pangsa pasar percaya infomasi tersebut sehingga tertarik untuk belanja di Shopee.

Berangkat dari efek kontekstual yang terdapat dalam iklan Shopee COD, agensi iklan mencoba menarik perhatian pangsa pasar dengan menggunakan musik, lagu dan gerakan sederhana dalam iklan. Iklan Shopee memang identik dengan musik dan gerakan uniknya. Pada pembaruan iklan Shopee selalu terdapat musik dan gerakan terbaru. Musik berserta lagu yang diiringi gerakan sederhana dalam iklan Shopee COD membangkitkan semangat dan kegembiraan. Sederhananya, ketika menyaksikan maupun mendengar iklan Shopee COD kawan tutur secara refleks ikut berdendang menyanyikan lagu dalam iklan tersebut.

Selain musik dan tarian, yang menjadi stimulus ostensif dalam iklan Shopee COD adalah warna oranye yang selalu ada sepanjang iklan. Warna oranye merupakan ciri khas Shopee, sehinga ketika pangsa pasar melihat warna oranye, mereka akan ingat aplikasi Shopee. Warna oranye tersebut terdapat pada jaket yang dikenakan oleh Tukul Arwana. Ia merupakan bintang utama yang berperan sebagai kurir Shopee. Warna oranye juga menjadi warna dasar kardus pembungkus barang apabila belanja di Shopee. Selain itu, warna oranye digunakan sebagai dasar tulisan dalam iklan. Selama 30 detik warna oranye selalu ada dalam penayangan iklan. Stimulus yang lain adalah pengulangan kata Shopee COD yang sering muncul selama iklan berlangsung. Pengulangan tersebut seperti mantra bagi 
pangsa pasar. Terhitung sebanyak 8 kali Shopee COD diucapkan. Dalam bentuk tulisan kata "Shopee COD" diubah menjadi "COD di Shopee" dan tulisan tersebut diulang sebanyak lima kali dengan adegan yang berbeda-beda.

\section{Pesan Agensi Iklan dalam Iklan Shopee COD}

Pesan yang disampaikan oleh agensi terdapat dalam tuturan pada iklan, baik secara implisit maupun eksplisit. Tuturan eksplisit tertuang dalam lirik lagu dan tulisan dalam iklan, sedangkan tuturan implisit dalam dilihat dengan mengaitkan konteks tuturan dengan adegan yang ada dalam iklan. Artinya tuturan implisit perlu ditelaah lebih dalam sehingga mendapatkan makna yang sama dengan apa yang disampaikan agensi iklan. Pada iklan ini agensi iklan ingin menekankan bahwa Shopee memiliki metode pambayaran baru, yaitu COD (bayar langsung di tempat). Kalimat Shopee COD menjadi kalimat yang paling sering disebut selama penayangan iklan berdurasi 30 detik. Kalimat tersebut disebut sebanyak delapan kali. Pengulangan delapan kali tersebut selalu muncul dalam setiap peralihan adegan. Tuturan sederhana "Shopee COD" namun diulang secara masif secara implikatur agensi iklan ingin menerangkan bahwa Shopee memiliki metode pembayaran yang baru, yaitu COD (bayar langsung di tempat) yang dapat digunakan oleh semua pengguna aplikasi Shopee.

Tuturan pertama dalam iklan tersebut terdapat pada lirik lagu yang berbunyi "Shopee COD-Shopee COD bayar langsung di tempat". Kalimat berdurasi 6 detik tersebut menampilkan Tukul Arwana sebagai kurir Shopee yang sedang mengantarkan paket kepada seorang perempuan muda pemilik warung makan sederhana di desa. Kesederhanaan warung tersebut dapat dilihat dari bangunan warung yang masih menggunakan anyaman bambu. Kemuculan tuturan tersebut dalam pembukaan iklan merupakan bentuk pengenalan terhadap Shopee COD.

COD merupakan akronim dari Cash on Delivery. Sederhananya agensi iklan mengenalkan kepada pangsa pasar bahwa COD sebagai metode pembayaran di tempat. Pembayaran di lakukan saat barang 
sudah sampai tujuan. Melalui adegan dalam iklan, agensi ingin menyampaikan bahwa COD menjadi salah sistem pembayaran yang memudahkan pembeli. Menggunakan sistem COD pembeli cukup menunggu barang sampai, kemudian membayarnya tanpa harus bepergian meninggalan pekerjaanya untuk melakukan transaksi. Bayar di tempat menjadi solusi bagi pembeli yang tidak dapat meninggalkan pekerjaanya. Pemiliki warung mengintepretasikan salah satu pekerjaan yang memiliki pertimbangan untuk ditinggalkan. Shopee COD menjadi pilihan untuk berbelanja tanpa harus meninggalkan pekerjaan.

Tuturan kedua yaitu "tanpa tabungan, tanpa rekening, pakai Shopee COD”. Tuturan tersebut disampaikan dalam durasi 6 detik dengan adegan Tukul Arwana (kurir) sedang mengirimkan paket kepada seorang petani yang tengah menanam padi di sawah. Secara harfiah tuturan tersebut jelas mengartikan bahwa belanja di Shopee dengan metode pembayaran COD sangat mudah, tanpa tabungan dan tanpa rekening. Secara implisit maksud agensi iklan terhadap kalimat tersebut yaitu ingin menyampaikan salah satu keunggulan menggunakan metode pembayaran COD adalah tanpa syarat apapun. Sejalan dengan kawan tutur iklan Shopee COD yaitu penduduk desa tentu Shopee berusaha memberikan kemudahan bagi penggunanya jika ingin berbelanja di Shopee. Apabila metode pembayaran sebelumnya mengharuskan pembeli memiliki rekening atau tabungan serta pergi ke ATM atau minimarket terdekat untuk melakukan transaksi maka dengan Shopee COD hal tersebut tidak perlu dilakukan. Kemudahan tersebut diharapkan mampu membantu pangsa pasar yang ingin berbelanja di Shopee namun tidak memiliki rekening.

Tuturan selanjutnya adalah "Shopee COD-Shopee COD pasti dapat gratis ongkir". Ketika berbelanja online tentu dikenai biaya pengiriman. Biaya pengiriman disesuaikan dengan alamat pembeli, sehingga murah dan mahalnya disesuaikan dengan jauh dekatnya lokasi pengiriman. Desa menjadi salah satu wilayah yang sulit dijangkau. Hal tersebut menjadi penyebab biaya pengiriman ketika belanja online menjadi lebih mahal. Mahalnya biaya pengiriman 
tentu menjadi pertimbangan tersendiri bagi pembeli. Toko yang berada di Shopee rata-rata berada di kota, sedangkan kali ini Shopee ingin menjangkau pelayanan hingga pelosok desa.

Gratis ongkir merupakan salah satu keuntungan yang didapat ketika menggunakan sistem pembayaran COD. Sesuai dengan namanya, gratis dalam KBBI daring berarti cuma-cuma (tidak dipungut biaya). Ongkir adalah akronim dari ongkos kirim yaitu biaya pengiriman. Gratis ongkir berarti pembeli tidak dikenakan biaya pengiriman, sehingga hal tersebut dapat menghemat biaya. Gratis ongkir diharapkan dapat dimanfaatkan oleh pembeli (pengguna Shopee) hingga ke pelosok desa. Kalimat tersebut ditayangkan dengan durasi 6 detik menampilkan adegan Tukul Arwana tengah mengantarkan paket kepada pembeli yang berprofesi sebagai tukang ojek. Dengan demikian tuturan Shopee COD pasti dapat gratis ongkir secara mendalam bertujuan untuk meyakinkan pangsa pasar untuk belanja di Shopee. Apabila menggunakan metode pembayaran COD pembeli juga dapat menikmati gratis biaya pengiriman, tentunya pembeli akan lebih menghemat biaya.

Selanjutnya yaitu tuturan Shopee COD-Shopee COD pasti dijamin aman. Maksud agensi iklan ingin meyakinkan pangsa pasar bahwa belanja di Shopee dengan COD dijamin keamanannya. Kata "pasti" digunakan penutur untuk meyakinkan kawan tuturnya. Pasti secara harfiah memiliki makna: tentu, tidak boleh tidak, sudah tetap. Agensi iklan ingin menghapus ketakutan yang dimiliki pangsa pasar ketika belanja online. Adapun ketakutan yang dimilki pangsa pasar yaitu penipuan, barang palsu, hingga barang rusak. Iklan Shopee COD hadir untuk menghilangkan ketakutan tersebut.

COD menjadi salah satu cara menjamin keamanan ketika berbelanja online di Shopee. Sistem bayar langsung di tempat mengurangi risiko penipuan, dengan demikian pembeli tidak perlu takut untuk belanja di Shopee. Kemanan tersebut digambarkan oleh Tukul Arwana (kurir) sedang mengantarkan paket kepada kuli bangunan, adegan tersebut berdurasi 7 detik, lebih lama jika dibandingan adegan yang lain. Meskipun tidak ada perbedaan yang 
signifikan dalam hal durasi, namun jaminan akan keamanan belanja di Shopee dengan metode COD ingin ditekankan oleh agensi pasar. Melihat pangsa pasar kali ini adalah penduduk desa yang cenderung memiliki kepercayaan rendah ketika berbelanja di marketplace. Adaya jaminan keamanan yang diberikan Shopee diharapkan mempu meningkatkan jumlah pembeli yang berbelanja di Shopee.

Tuturan terakhir yaitu Pakai Shopee COD. Kalimat persuasi tersebut merupakan simpulan dari tuturan sebelumnya. Secara implisit maupun eksplisit agensi iklan menyebutkan keuntungan belanja di Shopee dengan metode pembayaran COD, yaitu; seperti menghemat waktu, tenaga, biaya, mudah, hingga jaminan keamanan yang ditawarkan. Berdasarkan keutungan yang ada, agensi iklan ingin mengimbau pangsa pasar untuk berbelanja di Shopee dengan pilihan metode pembayaran COD (bayar di tempat).

Tuturan Pakai Shopee COD hanya berdurasi 3 detik. Durasi yang paling sedikit jika dibandingkan dengan tuturan lainnya, namun dalam tuturan tersebut agensi iklan menampilkan adegan semua bintang iklan berkumpul di jalan setapak di tengah-tengah sawah. Masing-masing bintang iklan memegang kardus berwarna oranye yang bertuliskan Shopee. Kardus tersebut merupakan gambaran barang yang dibeli pembeli, sedangkan Tukul Arwana yang berperan sebagai kurir memegang uang. Berkumpulnya semua bintang iklan dengan pekerjaan berbeda-beda di suasana desa lagilagi menegaskan bahwa agensi iklan mengajak, meyakinkan pangsa pasar untuk berbelanja di Shopee dengan sistem COD karena dijamin aman, mudah, dan hemat.

Tuturan dalam iklan Shopee COD tidak hanya tertuang dalam lirik lagu dan adegan, tetapi juga dalam bentuk tulis. Adapun tuturan berbentuk tulisan yang muncul dalam iklan adalah sebagai berikut; COD di Shopee; bisa bayar di tempat, tanpa tabungan, khusus pengguna baru gatis ongkir Rp 0 , dijamin aman. Tuturan yang tertulis merupakan penyederhanaan dari tuturan yang terkandung dalam lirik lagu. Tujuannya untuk memudahkan pangsa pasar mengingat poin-poin keuntungan COD di Shopee dengan sederhana. 
Berbagai tuturan yang disampaikan agensi iklan sebagai penutur secara keseluruhan adalah mengenalkan metode COD sebagai metode pembayaran baru di Shopee. COD bayar langsung di tempat menawarkan berbagai kemudahan dan keuntungan, khususnya bagi penduduk desa yang diyakini lebih tertinggal jika dibandingkan penduduk di kota. Adanya sistem tersebut diharapkan mampu membantu pangsa pasar yang terkendala berbagai hal dapat memenuhi kebutuhan maupun keinginan dengan aman.

\section{Derajat Relevansi Iklan Shopee COD dengan Kawan Tutur}

Berdasarkan tuturan yang terdapat dalam iklan Shopee COD, tuturan tersebut memiliki derajat relevansi yang kuat terhadap pangsa pasarnya. Derajat relevansi dapat diukur dari sejauh mana iklan tersebut dipahami kawan tutur. Tuturan yang terdapat dalam iklan Shopee COD memuat banyak efek kontekstual yang mudah dipahami karena tuturan disampaikan dengan bahasa yang sederhana dan jelas. Bahasa yang digunakan tentu disesuaikan dengan kawan tuturnya. Tuturan yang diungkapkan melalui adegan para bintangnya memberikan konotasi bahwa Shopee manjangkau pangsa pasar hingga penduduk desa. Kemudahan yang ditawarkan menghilangkan keraguan penduduk desa untuk berbelanja di Shopee.

\section{PENUTUP}

Berdasarkan analisis di atas, berikut beberapa hal yang dapat disimpulkan. Pertama, iklan Shopee COD merupakan bentuk komunikasi antara agensi iklan sebagai penutur dengan kawan tuturnya, yaitu pengguna aplikasi Shopee khususnya penduduk desa. Kedua, iklan Shopee COD memanfaatkan efek kontekstual yaitu anggapan yang dimiliki oleh agensi pasar dan asumsi yang beredar di benak pangsa pasar. Anggapan tersebut yaitu penduduk desa ingin berbalanja di Shopee, ketakutan berbelanja online, dan metode pembayaran yang ditawarkan. Efek kontekstual tersebut digunakan oleh agensi iklan untuk menyusun tuturan dan strategi untuk menarik perhatian pangsa pasar. Selain itu, penggunaan stimulus ostensif berupa lagu yang diiringi dengan gerakan, penggunaan 
warna oranye yang menjadi ciri khas Shopee, dan pengulangan kata Shopee COD untuk menarik perhatian pangsa pasar. Ketiga, terdapat tuturan implisit dan ekplisit dalam iklan. Tuturan tersebut untuk menyampaikan pesan dari agensi iklan kepada kawan tutur. Adapun pesan tersebut adalah belanja di Shopee dengan metode bayar di tempat dijamin aman dan mudah. Keempat, iklan Shopee COD memiliki derajat relevansi yang tinggi karena memiliki efek kontekstual dan penggunaan bahasa yang sederhana sehingga mudah dipahami pangsa pasar.

\section{DAFTAR PUSTAKA}

Artaya, I Putu dan Tubagus Purworusmiardi. (2019). Efektifitas Marketplace dalam Meningkatkan Konsentrasi Pemasaran dan Penjualan Produk bagi UMKM di JawaTimur. https://www. researchgate.net/publication/332523654_EFEKTIFITAS_ MARKETPLACE_DALAM_MENINGKATKAN_ KONSENTRASI_PEMASARAN_DAN_PENJUALAN_ PRODUK_BAGI_UMKM_DI_JAWA-TIMUR

Grice, H.P. (1975). Logic and Conversation, Syntax and Semantic, Speech Act, 3. New York: Academic Press.

Haryani, Dwi Septi. (2019). Pengaruh Periklanan dan Promosi Penjualan Terhadap Keputusan Pembelian Pada Perumahan Griya Puspandari Asri Tanjung Pinang. Jurnal Dimennsi, Vol. 8, No. $1,54-70$

Jaiz, Muhammad. (2014). Dasar-dasar Periklanan. Yogyakarta: Graha Ilmu.

Kodong, Frans Richard, dkk. (2012). Model Aplikasi E-Market sebagai Sarana Promosi dan Tukar Menukar Infomasi Antara Penjual dan Pembeli. Jurnal Telematika, Vol, 8, No. 2, 75-84.

Kotler, Philip dan Kevin Lane Keller. (2007). Manajemen Pemasaran Jilid I, Edisi ke-12. Jakarta: PT Indeks.

Kushartanti, dkk. (2009). Pesona Bahasa: Langkah Awal Memahami Linguistik. Jakarta: PT Gramedia Pustaka Utama. 
Lutfiyani, Siska, dkk. (2020). Sarkasme pada Media Sosial Twitter dan Implikasinya terhadap Pembelajaran Bahasa Indonesia di SMA. Jurnal Tabasa, Vol,1, No. 02, 270-281

Megawati. 2018 Analisis Teori Relevansi dalam Acara Ini Talk Show sebagai Kritik terhadap Prinsip Kerja sama Grice.

Nadar, F.X. (2013). Pragmatik \& Penelitian Pragmatik. Yogyakarta: Graha Ilmu.

Nasanius, Yassir. (2007). Pelbba 18 Pertemuan Linguistik Pusat Kajian Bahasa dan Budaya Atma Jaya: Kedelapan Belas. Jakarta: Yayasan Obor Indonesia.

Normalita, Aulia. (2020). Parameter Tindak Tutur Santri dan Ustazah pada Pembelajaran Kitab Amsilati di Pesantren Darussalam. Jurnal Tabasa, vol., 1, No 2, 212-228

Nurjanah, Neneng. (2016). Membedah Relevansi dalam Iklan WRP. Jurnal Dialetika, 3(1), 67-86

Nurjanah, Neneng dan Rifka A. Pratiwi. (2019). Citra Perempuan Berhijab dalam Iklan Shampo: Sebuah Kajian Pragmatik. Jurnal Pena Indonesia, Vol. 5, No. 2, 79-78.

Purnama, Lingga. (2001). Strategic Marketing Plan. Jakarta:Gramedia Pustaka Utama.

Puspitasari, Sulfia. 2015. Study of Conceptual Metaphors in Indomie Tv Commercial. Skripsi Univeristas Brawijaya, Malang.

Putrayasa, Ida Bagus. (2014). Pragmatik. Yogyakarta: Graha Ilmu.

Putri, Nurul Panca, dkk. (2020). Semiotik Roland Barthes pada Cerpen Tunas Karya Eko Tunas dan Implikasinya dalam Pembelajaran Bahasa Indonesia. Jurnal Tabasa, vol., 1, No 2, 250-267

Rozul dan Agus Ramdhani Nugraha. (2018). Perancangan Sistem Informasi E-markerplace Original Clothing Indonesia Berbasis Web. Jumanta, vol., 01, No. 01, 161-170.

Simatupang, Taufik H. (2004). Aspek Hukum Periklanan Perspektif Perlindungan Konsumen (Cetakan ke-1). Citra Bakti: Bandung. 
Sperber dan Deirde Wilson. (2005). Pragmatics dalam F Jackson M Smith Oxford Handbook of Contemporary Philosophy.

Wulandari, Oryz Agnu Dian, dkk. (2020). Analisis Pemanfaatan Marketplace dalam Meningkatkan Pendapatan Bagi Penjualan Produk UMKM di Purbalingga. Jurnal Ekonomi Manajemen, vol.6, No 2. 96-101

Yule, George. (2006). The Study of Language. New York: Cambridge University Press.

Yustiani, Rini dan Yunanto. (2017). Peran Marketplace sebagai Alternatif Bisnis Era Teknologi Informasi. Jurnal Komputa, vol. 6, No. 2. 43-47. 